Int. J. Electrochem. Sci., 11 (2016) $10306-10319$

\title{
Electrochemical Behaviour of Galvanized Steel Embedded in Concrete Exposed to Sand Contaminated with $\mathrm{NaCl}$
}

\author{
M.A. Baltazar-Zamora ${ }^{1}$, G. Santiago-Hurtado ${ }^{2}$, V.M. Moreno $L^{3}$, R. Croche $B^{4}$, M. de la Garza ${ }^{5}$., \\ F. Estupiñan $L^{5}$., P. Zambrano $R^{5}$., C. Gaona-Tiburcio, \\ ${ }^{1}$ Facultad de Ingeniería Civil - Xalapa, Universidad Veracruzana, Circ. G. Aguirre Beltrán S/N, Lomas \\ del Estadio, Xalapa, Veracruz, México, CP 91000 \\ ${ }^{2}$ Doctorado en Ingeniería, FIME, Universidad Veracruzana, Xalapa, Veracruz, México. \\ ${ }^{3}$ Facultad de Ingeniería Civil - Unidad Torreón, UADEC, Torreón, Coahuila, México. \\ ${ }^{4}$ FIME, Universidad Veracruzana, Xalapa, Veracruz, México. \\ ${ }^{5}$ Universidad Autónoma de Nuevo León. FIME - CIIIA. Av. Universidad S/N. Ciudad Universitaria. \\ San Nicolás de los Garza, Nuevo León, México. \\ *E-mail: citlalli.gaona@gmail.com
}

doi: $10.20964 / 2016.12 .28$

Received: 6 July 2016 / Accepted: 13 September 2016 / Published: 10 November 2016

This research evaluates the corrosion of reinforced concrete, exposed to marine sand, simulating what happens with the elements of laying of foundations of all concrete structures constructed on coasts of Mexico and the world. In such concrete specimens a steel bar AISI 1018 and Galvanized Steel was embedded as reinforcement, the mixed concrete was of ratio $\mathrm{w} / \mathrm{c}=0.45\left(\mathrm{f}^{\prime} \mathrm{c}=350 \mathrm{~kg} / \mathrm{cm}^{2}\right)$, according to ACI 211.1, using two type cements CPC 30R and CPC 30R RS. The corrosion rate was evaluated by electrochemical techniques, corrosion potential $\mathrm{E}_{\text {corr }}$ (ASTM C-876-09) and Linear Polarization Resistance (ASTM-G59). These specimens were exposed in a marine sand contaminated with 0, 1, 2 and $3 \% \mathrm{NaCl}$, the exposure time was 260 days where, according to the electrochemical results of $\mathrm{E}_{\text {corr }}$ and $\mathrm{I}_{\text {corr }}$, we could determine that the better performance of the specimens was galvanized steel and concrete made with cement CPC 30R RS, this research demonstrated the importance of developing special to elaborated concrete durability in aggressive environment such as is the ground where uproots all reinforced concrete structures.

Keywords: Foundations, Soil, Reinforced Concrete, Corrosion, Chlorides.

\section{$\underline{\text { FULL TEXT }}$}

(C) 2016 The Authors. Published by ESG (www.electrochemsci.org). This article is an open access article distributed under the terms and conditions of the Creative Commons Attribution license (http://creativecommons.org/licenses/by/4.0/). 